\title{
Recovery of Cymodocea nodosa (Ucria) Ascherson photosynthesis after a four-month dark period
}

\author{
ERIK-JAN MALTA ${ }^{1,2}$, FERNANDO G. BRUN ${ }^{1,3}$, JUAN J. VERGARA ${ }^{1}$, \\ IGNACIO HERNÁNDEZ ${ }^{1}$ and J. LUCAS PÉREZ-LLORÉNS ${ }^{1}$ \\ ${ }^{1}$ Área de Ecología, Departamento de Biología, Facultad de Ciencias del Mar y Ambientales, Universidad de Cádiz, \\ 11510 Puerto Real, Cádiz, Spain. \\ ${ }^{2}$ Present address: ALGAE - Marine Plant Ecology Research Group, CCMAR, Universidade do Algarve, Gambelas, \\ 8005-139 Faro, Portugal. E-mail: emalta@ualg.pt \\ ${ }^{3}$ Present address: Netherlands Institute of Ecology (NIOO-KNAW), Centre for Estuarine and Marine Ecology, \\ Korringaweg 7, 4401 NT Yerseke, The Netherlands.
}

SUMMARY: Cymodocea nodosa plants were dark incubated for four months. The potential of reactivating photosynthesis was tested in an experiment in which half of the plants were reilluminated (HL) while the other half were grown under very low irradiance levels (LL). Photosynthesis was measured using PAM fluorescence and tissue nutrient and carbohydrate contents were analysed. Photosynthetic efficiency $\left(\mathrm{F}_{\gamma} / \mathrm{F}_{\mathrm{m}}\right)$ in HL plants increased from 0 to 0.58 , whereas LL plants remained inactive. Photosynthetic parameters also increased, resulting in a final $\mathrm{I}_{\mathrm{k}}$ of $97.5 \mu \mathrm{mol} \mathrm{m} \mathrm{m}^{-2} \mathrm{~s}^{-1}$. Leaf shedding led to a negative mean RGR in HL plants. Tissue $\mathrm{C}$ and $\mathrm{N}$ dropped considerably during dark incubation in both rhizomes and shoots. Starch content was nearly equal for rhizomes and shoots $(4.3 \mathrm{mg} / \mathrm{g} \mathrm{DW})$ and was not affected by dark incubation. In contrast, sucrose content dropped from $40.0 \mathrm{mg} / \mathrm{g}$ DW to zero in shoots and from 240 to $40.0 \mathrm{mg} / \mathrm{g}$ DW in rhizomes in HL plants. We conclude that $C$. nodosa is capable of recovering photosynthetic activity after four months darkness, which is considerably longer than the $80 \mathrm{~d}$ recorded so far for a seagrass. Stored carbohydrates, more specifically sucrose, play an important role in both survival and reactivation.

Keywords: Cymodocea nodosa, chlorophyll fluorescence, light, carbohydrates, survival.

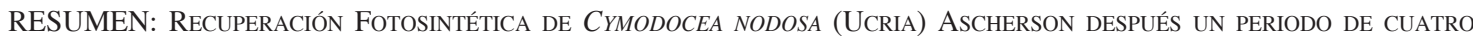
MESES EN OSCURIDAD. - La capacidad de recuperación de la fotosíntesis se ha investigado en la fanerógama marina Cymodocea nodosa. Para ello, se diseñó un experimento en el que la mitad de las plantas se cultivaron en condiciones de luz saturante (HL) y la otra mitad en condiciones de luz muy baja (LL), tras un precultivo de 4 meses en oscuridad. Se examinó la actividad fotosintética mediante la señal de fluorescencia del PAM y se determinó el contenido interno en nutrientes y de hidratos de carbono. La eficacia fotosintética $\left(\mathrm{F}_{/} / \mathrm{F}_{\mathrm{m}}\right)$ se incrementó desde 0 hasta 0,58 en las plantas de HL, mientras las plantas de LL permanecieron fotosintéticamente inactivas. Los parámetros fotosintéticos también se incrementaron, obteniéndose valores finales para $\mathrm{I}_{\mathrm{k}}$ de $97,5 \mu \mathrm{mol}$ fotones $\mathrm{m}^{-2} \mathrm{~s}^{-1}$. Las plantas de $\mathrm{HL}$ mostraron valores medios negativos de la tasa de crecimiento relativo, atribuible al desprendimiento de hojas. El contenido interno de carbono y nitrógeno disminuyó considerablemente durante el periodo de oscuridad tanto en la biomasa epigea como hipogea. El contenido interno en almidón permaneció constante en ambos tejidos $(4,3 \mathrm{mg} / \mathrm{g} \mathrm{DW})$, no estando afectado por el periodo de oscuridad. El contenido interno de sacarosa mostró un patrón opuesto, disminuyendo desde $40 \mathrm{mg} / \mathrm{g}$ DW a valores cercanos a cero en haces, y en rizomas desde 240 a $40 \mathrm{mg} / \mathrm{g}$ DW, en plantas de HL. En conclusión, $C$. nodosa recuperó la actividad fotosintética tras 4 meses en oscuridad, un periodo considerablemente mayor al registrado anteriormente para otras especies de fanerógamas $(80$ días). Los carbohidratos de reserva, y más concretamente la sacarosa, juega un papel crucial tanto en la supervivencia como en la reactivación fotosintética.

Palabras clave: Cymodocea nodosa, fluorescencia de clorofila, luz, hidratos de carbono, supervivencia. 


\section{INTRODUCTION}

Seagrass ecosystems, renowned for their high productivity and high biodiversity, are declining rapidly due to the effects of human activities. Large losses in the world's seagrass stands have been attributed to eutrophication, siltation (caused by deforestation and land clearing) and pollution (e.g. Short and Wylie-Echeverria, 1996). Reduction of the underwater light climate due to increases in particulate matter, epiphytes and macroalgal blooms is the most significant cause of seagrass decline (Short et al., 1995; Onuf, 1996; Hemminga and Duarte, 2000; McGlathery, 2001). This reduction can mean that plants are subjected to extended periods of complete or nearly complete darkness which is often accompanied by reduced water velocities and oxygen levels. This is mostly caused by human activities that lead to eutrophication-induced phytoplankton blooms and siltation, as well as natural processes (e.g. heavy storms, burial by subaqeous dune movement) (Moore et al., 1997; Longstaff and Dennison, 1999; Hauxwell et al., 2001; McGlathery, 2001; Cabello-Pasini et al., 2002).

Various authors have experimentally studied the effect of reducing irradiance on the growth and photosynthesis of a number of seagrass species. Most of these studies, however, report on the effect of low light (Lee and Dunton, 1997; Ruiz and Romero, 2001; overview in Table 5 of Longstaff et al., 1999). The light used in these studies was usually around or just below the light compensation point for photosynthesis of the species considered (i.e. $\geq 5 \%$ surface irradiance depending on the species and the location). Few studies examine survival after a period in almost complete darkness (Bulthuis, 1983; Longstaff et al., 1999; Cabello-Pasini et al., 2002). Furthermore, survival and recovery times after a period of darkness or low light vary greatly between species (Longstaff et al., 1999; Ruiz and Romero, 2001). Hence, to be able to make predictions about the effects of processes leading to temporal darkness on seagrass systems, more species-specific information is needed.

The capacity to accumulate and remobilise carbohydrates in the rhizomes (specifically starch and sucrose) is essential for seagrass species to survive a period in darkness (Lee and Dunton, 1997; Touchette and Burkholder, 2000; Brun et al., 2003; Peralta et al., 2002). Storage potential and subsequent remobilisation appear to be species specific and different for the major storage products, sucrose and starch. Little is known about the dynamics of these carbohydrates during recuperation.

A problem in assessing survival capacity is the slow growth of many seagrass species. If observations are to be made on rhizome or leaf growth, or new leaf formation, long experiments are required. In Cymodocea nodosa, for example, new leaf formation takes 31.7 days on average (Hemminga and Duarte, 2000, p. 50). Furthermore, the plants probably need even more time when recovering from adverse conditions. A plant's first step in survival would be to re-active photosynthesis. This can be monitored by measuring changes in the amount of variable chlorophyll $a$ fluorescence using a PAM fluorometer. PAM fluorescence has become a common tool in plant research and has been applied in several seagrass studies (e.g. Hanelt, 1992; Ralph and Burchett, 1995; Beer and Björk, 2000). This method was applied by Longstaff et al. (1999) to assess survival of Halophila ovalis after a dark period. It must be noted that reactivation of photosynthesis alone does not ensure eventual plant survival; however, it can be considered a strong indication that a plant is likely to survive.

In a pilot experiment, we tested the suitability of washed, natural sediment as a substrate for long term cultivation of the seagrass species Cymodocea nodosa and Zostera noltii. The plants were cultivated successfully during five months. After this period, it was decided to simulate a "darkness event" as may occur due to siltation after a heavy storm or subaqeous dune movement. This event is characterised by (nearly) complete darkness, reduced flow velocities and reduced oxygen levels (Marbà and Duarte, 1994; Hauxwell et al., 2001; McGlathery, 2001; Cabello-Pasini et al., 2002). After four months, all Z. noltii plants had died and partly decomposed; however, the apical plants of $C$. nodosa genets were still alive. An experiment was set-up with the aim of determining the capacity of $C$. nodosa to recuperate photosynthesis, which was monitored by $\mathrm{Chl} a$ fluorescence and the use of carbohydrates during this recovery period. To obtain an idea of the degree of recuperation, photosynthesis parameters of the incubated plants were compared with those of freshly collected plants from two sites differing in light climate. The results are discussed in terms of the capacity of $C$. nodosa to survive prolonged periods of darkness. 


\section{MATERIAL AND METHODS}

\section{Collection sites and cultivation}

Plants for the dark incubation and recovery experiment were collected in July 2001 from the Río San Pedro tidal inlet, Puerto Real, southwest Spain $\left(36^{\circ} 31^{\prime} \mathrm{N}, 6^{\circ} 14^{\prime} \mathrm{E}\right)$. A second batch of plants was collected from the same site and from an intertidal pool (Caño de Cortadura), situated approximately $0.5 \mathrm{~km}$ west of the first site in May 2002. These plants were only used for determining the photosynthesis parameters and were transported to the laboratory in cool boxes. Fluorescence parameters were determined immediately upon arrival (within 30 minutes after collection). In both sites, plants were taken from the upper subtidal zone; however, light conditions between the sites differed considerably. Current velocities are much higher in Río San Pedro than in the relatively sheltered Caño de Cortadura and depend heavily on wind conditions. Consequently, turbidity (and hence light conditions) in the Río shows high variability, while the Caño has a permanent high turbidity due to high sedimentation levels. Summer irradiance (PAR) levels in the upper subtidal area of the Río have been found to range from 20 to $30 \mu \mathrm{mol}$ photons $\mathrm{m}^{-2} \mathrm{~s}^{-1}$ (high tide after a storm) to $\geq 1500 \mu \mathrm{mol}$ photons $\mathrm{m}^{-2} \mathrm{~s}^{-1}$ (low tide, clear waters), while values in the Caño ranged between 0 to $5 \mu \mathrm{mol}$ photons $\mathrm{m}^{-2} \mathrm{~s}^{-1}$ (high tide) and 150 to $200 \mu \mathrm{mol}$ photons $\mathrm{m}^{-2} \mathrm{~s}^{-1}$ (low tide) (E.-J. Malta, unpubl. data).

For the dark incubation, Zostera noltii Hornem. and Cymodocea nodosa (Ucria) Ascherson genets consisting of 5 to 10 horizontal nodes with their corresponding shoots were collected. Five genets, consisting of 3 to 4 shoots, were divided into shoots and rhizomes plus roots, weighed wet, oven-dried $(72 \mathrm{~h}$, $60^{\circ} \mathrm{C}$ ), weighed again and stored dry for later $\mathrm{C}: \mathrm{N}$ analyses (referred to as "field"). The other plants were cultivated at room temperature in a $130 \mathrm{~L}$ aquarium holding filtered natural ocean water (renewed monthly) and natural sediment, which was washed with $\mathrm{H}_{2} \mathrm{SO}_{4}$ and tap water to remove organic material. Light was provided by fluorescence tubes (Philips TLD 18W/54; $150 \mu \mathrm{mol}$ photons $\mathrm{m}^{-2}$ $\mathrm{s}^{-1}$ ) under a 14:10 L:D regime. Light was measured using a spherical quantum sensor (LI-193SA, LICOR). Water was continuously circulated through a biological carbon filter and aerated. No nutrients were added.

\section{Experimental set-up}

After 5 months of successful cultivation, a "darkness event" was simulated as may occur due to siltation after a heavy storm or subaqeous dune movement and which can be characterised by (nearly) complete darkness, reduced flow velocities and reduced oxygen levels (Marbà and Duarte, 1994; Hauxwell et al., 2001; McGlathery, 2001; CabelloPasini et al., 2002). These conditions were obtained by turning off the light, water circulation and aeration. The amount of daylight that reached the aquarium through a small window was negligible (light intensity below detection limit $[=0.1 \mu \mathrm{mol}$ photons $\mathrm{m}^{-2} \mathrm{~s}^{-1}$ ] of the light meter). After four months of darkness all Z. noltii plants had died and partially decomposed while only the apical shoots of the $C$. nodosa plants still appeared to be alive.

An experiment was set up to detect the recovery of $C$. nodosa photosynthesis. Plants were harvested and four apical shoots (referred to as "initial"), each with two rhizome internodes and attached roots were divided into roots, rhizomes and shoots, ovendried as above and stored for later $\mathrm{C}: \mathrm{N}$ and carbohydrate analyses. The other plants were divided into 14 experimental units, consisting of the apical shoot and two rhizome internodes with attached roots. The units were carefully blotted dry, weighed, and transferred to two $30 \mathrm{~L}$ aquaria (7 plants per aquarium) filled with washed sediment and filtered ocean water under continuous aeration. The aquaria were placed in a cultivation cabinet (D-1400-3BL, ASL) at a temperature of $18^{\circ} \mathrm{C}$. One aquarium was illuminated with fluorescent tubes (Philips TLD $18 \mathrm{~W} / 54 ; 150 \mu \mathrm{mol}$ photons $\mathrm{m}^{-2} \mathrm{~s}^{-1}$ ) under a $16: 8$ L:D regime ("high light" [HL] treatment). A $16 \mathrm{~h}$ photoperiod was chosen rather than a $14 \mathrm{~h}$ as in the incubation as it represented more closely the natural photoperiod in April in southern Spain. The other aquarium, which acted as a control, was not illuminated. Nevertheless, reflections of the lights of the HL treatment on the walls of the cultivation cabinet could not be avoided, resulting in an irradiance of 10 to $15 \mu \mathrm{mol}$ photons $\mathrm{m}^{-2} \mathrm{~s}^{-1}$; hence, this treatment will be referred to as "low light" (LL). Water was changed weekly and enriched with nitrate $\left(5 \mu \mathrm{M}\right.$ as $\left.\mathrm{NaNO}_{3}\right)$ and phosphate $(0.25 \mu \mathrm{M}$ as $\left.\mathrm{NaH}_{2} \mathrm{PO}_{4} \cdot \mathrm{H}_{2} \mathrm{O}\right)$.

After 32 days, a sudden and explosive growth of phytoplankton cells in the HL treatment occurred, leading to severely reduced light levels. As it was 
feared that this might have affected the seagrasses, considering the observed drop in photosynthetic efficiency, it was decided to end the experiment at this stage. All plants were harvested, blotted dry and weighed, after which they were divided into roots, shoots and rhizomes and oven-dried for carbohydrate analyses. There was not enough material available to carry out $\mathrm{C}: \mathrm{N}$ analyses as well. Relative growth rates (RGR [mg FW d ${ }^{-1}$ ) were determined by subtracting initial from final fresh weight and dividing this value by the number of days.

\section{Photosynthesis measurements}

Photosynthesis was measured by monitoring chlorophyll $a$ fluorescence using a pulse-amplitudemodulation (PAM) fluorometer (PAM-2000, Walz). Measurements were made on days 2 to $5,7,10,12$ 14, 17-21, 24-26, 28 and 32 of the experiment. See a.o. Schreiber et al. $(1994,1999)$ for details of this technique. As fluorescence values can vary both in different positions in the leaf as well as between leaves in one plant (Kamermans et al., 1999; Enríquez et al., 2002), for comparisons between plants it is important to take the measurement at the same position and preferably in the same leaf of each plant. Initially, measurements were taken approximately $0.5 \mathrm{~cm}$ above the leaf base of the second youngest leaf of all the plants. However, as all plants in the HL aquarium shed their leaves within a week, fluorescence in both the HL and the LL plants were taken from the part of the sheath that covers the youngest leaves. The leaf sheath itself is colourless and does not contain pigments and therefore does not influence the fluorescence signal. Dark leaf clips (Diving-LC, Walz) were mounted on the sheath of each plant in which the PAM sensor was inserted. Following Hanelt (1998), a five s weak far-red pulse was applied to oxidise the electron transport chain, after which the shutters of the clips were closed and the plants were dark acclimatised for 5 minutes. Then, the shutters were opened and the measuring light of the PAM was turned on, so that the base fluorescence $\left(\mathrm{F}_{0}\right)$ could be measured. A $0.6 \mathrm{~s}$ saturating light pulse $\left(\approx 4000 \mu \mathrm{mol}\right.$ photons $\left.\mathrm{m}^{-2} \mathrm{~s}^{-1}\right)$ was then administered to measure maximum fluorescence $\left(\mathrm{F}_{\mathrm{m}}\right)$ and to calculate the variable fluorescence $\left(\mathrm{F}_{\mathrm{v}}=\mathrm{F}_{\mathrm{m}}-\mathrm{F}_{0}\right)$ and the maximum quantum yield of photosynthesis $\left(\mathrm{F}_{\mathrm{v}} / \mathrm{F}_{\mathrm{m}}\right)$. Duplicate $5 \mathrm{~mL}$ water samples were taken from both aquariums just before the change of water and were obscured for 5 minutes after which $\mathrm{F}_{\mathrm{v}} / \mathrm{F}_{\mathrm{m}}$ was measured as described above to detect potential background fluorescence.

From day 12 on, when $\mathrm{F}_{\mathrm{v}} / \mathrm{F}_{\mathrm{m}}>0$ was observed for the first time in HL plants, the measurements were followed by determining photosynthesis vs. irradiance curves (P-I curves) as rapid light curves (RLCs). With this method, plants are subjected briefly to a certain light level, after which the fluorescence parameters are measured from which the relative electron transport rate (rETR, a measure of photosynthesis) can be calculated (e.g. Ralph et al., 1998; White and Critchley, 1999; Bischof et al., 2000). Plants were subjected to a series of ten increasing light intensities, ranging from 12 to $204 \mu \mathrm{mol}$ photons $\mathrm{m}^{-2} \mathrm{~s}^{-1}$, using the internal LED from the PAM as the light source. After $30 \mathrm{~s}$ exposure time at each light intensity, steady-state fluorescence $(F)$ was measured and a saturating light pulse was administered after the maximum fluorescence in the light $\left(\mathrm{F}_{\mathrm{m}}{ }^{\prime}\right)$ was measured. From these measurements the effective quantum yield $\left(\Delta \mathrm{F} / \mathrm{F}_{\mathrm{m}}{ }^{\prime}=\left[\mathrm{F}_{\mathrm{m}}{ }^{\prime}-\mathrm{F}\right] / \mathrm{F}_{\mathrm{m}}{ }^{\prime}\right)$ and the rETR were calculated $\left(\mathrm{rETR}=\Delta \mathrm{F} / \mathrm{F}_{\mathrm{m}}{ }^{\prime} \times \mathrm{PAR} \times 0.5\right)$, where PAR is divided by two assuming that both photosystems absorbed an equal amount of light.

\section{Chemical analyses}

Tissue carbon and nitrogen contents of field and initial plants were determined on a Perkin-Elmer $240 \mathrm{C}$ elemental CHN analyser. Soluble sugars were extracted by boiling dried samples in $80 \%$ ethanol. Extracts were evaporated to dryness at room temperature, redissolved in distilled water and analysed spectrophotometrically using a resorcinol assay standardised to sucrose (Hubber and Israel, 1982). Starch was extracted from the ethanol-insoluble fraction overnight in $1 \mathrm{~N} \mathrm{NaOH}$ and analysed spectrophotometrically using an anthrone assay standardised to sucrose (Yemn and Willis, 1954).

\section{Data analyses}

Irradiance vs. rETR data were fitted to the equation of Jassby and Platt (1976):

$$
r E T R=r E T R_{m} \tanh \left(\frac{\alpha P A R}{r E T R_{m}}\right)
$$

to estimate maximum $\mathrm{rETR}\left(\mathrm{rETR}_{\mathrm{m}}\right)$ and initial slope $(\alpha)$ using least square, non-linear regression. Estimates were obtained in an iterative procedure 
with the Quasi-Newton method using the Statistica 5.5 software package (StatSoft, 1999). The onset of light saturation $\left(\mathrm{I}_{\mathrm{k}}\right)$ was calculated as $\mathrm{rETR}_{\mathrm{m}} / \alpha$. To ecologically characterise the photosystem of the HL plants, their photosynthetical characteristics (the RLC parameters) at the end of the experiment were compared with those collected in 2002. The RLC parameters of day 26 were used for this as it was felt that the phytoplankton bloom might have interfered with the photosynthesis data collected on day 32 . Differences in RLC parameters between HL plants and plants from the field sites were tested for significance using a one-way ANOVA, followed by a Tukey honest significant difference test for unequal sample sizes (Spjøtvoll and Stoline, 1973). Data were tested for heteroscedasticity with Bartlett's test for homogeneity (Sokal and Rohlf, 1995).

Considering the comparison of means of HL and LL plants, we are aware of the fact that our set-up only included one aquarium per treatment (for technical reasons it was not possible to use more aquaria). Hence, the individual measurements of each plant per treatment are pseudoreplicates, which impedes a statistical comparison of these data. All possible measures were taken to assure that the variation between aquaria could only be attributed to the light intensity: aquaria were placed in the same cultivation cabinet, air was provided by one single pump, sediment was taken from the same batch and only divided after treatment, water was also taken from the same batch and was only divided after filtration and nutrients were taken from one single stock solution. Furthermore, the differences between treatments were generally very large compared to the variation between plants within treatments (especially in the case of the fluorescence measurements). Hence, the problem of pseudoreplication is not considered to present a major problem for interpreting the results. Starch data were tested for differences between plant parts and treatments using a 2-way ANOVA, after a Box-Cox power transformation $\left(y^{\prime}=y^{\lambda}\right.$, with $\lambda=-1.793$, Box and Cox, 1964) which removed heteroscedasticity. $\lambda$ was estimated in an iterative procedure using the Statistica 5.5 software package (StatSoft, 1999). Sucrose data remained heteroscedastic after transformation. Therefore, plant parts were analysed separately for a treatment effect using the nonparametric KruskalWallis test (Sokal and Rohlf, 1995). Differences in tissue $\mathrm{C}$ and $\mathrm{N}$ contents between field and initial plants could not be tested for significance because the roots and rhizomes of field plants were not separated before analysis; hence a direct comparison was not possible.

\section{RESULTS AND DISCUSSION}

\section{Fluorescence measurements}

One LL plant died during the experiment, hence averages represent six plants. LL plants showed a constant $\mathrm{F}_{0}$ value of $0.225 \pm 0.026$ (average $\pm \mathrm{SD}$ of all plants over the whole period) with insignificant day to day variations. However, no photosynthetic activity whatsoever (defined as $\mathrm{F}_{\mathrm{v}} / \mathrm{F}_{\mathrm{m}}>0$ ) could be measured in the LL plants. In HL plants, $\mathrm{F}_{\mathrm{v}} / \mathrm{F}_{\mathrm{m}}$ values higher than 0 were detected for the first time on day 12 in one plant. From days 13 to 18 all plants initiated photosynthesis and $\mathrm{F}_{\mathrm{v}} / \mathrm{F}_{\mathrm{m}}$ continued to increase although a large variation was found between plants (Fig. 1). The increases in $F_{v} / F_{m}$ could be attributed almost entirely to increases in $\mathrm{F}_{\mathrm{m}}$, while $\mathrm{F}_{0}$ remained practically constant and similar to that of LL plants $(0.255 \pm 0.063$, overall average $)$. On the last day a sudden drop in $\mathrm{F}_{\mathrm{m}}$ resulted in a lower $F_{v} / F_{m}$. On this day an extensive phytoplankton bloom had developed. $\mathrm{F}_{0}$, measured in water samples from this day, was $0.059 \pm 0.001, \mathrm{~F}_{\mathrm{v}} / \mathrm{F}_{\mathrm{m}}$ was $0.588 \pm 0.003$; no fluorescence was detected in water samples from the LL aquarium or in samples from the HL aquarium taken earlier.

The fluorescence data show that $C$. nodosa plants are capable of reactivating photosynthesis after a

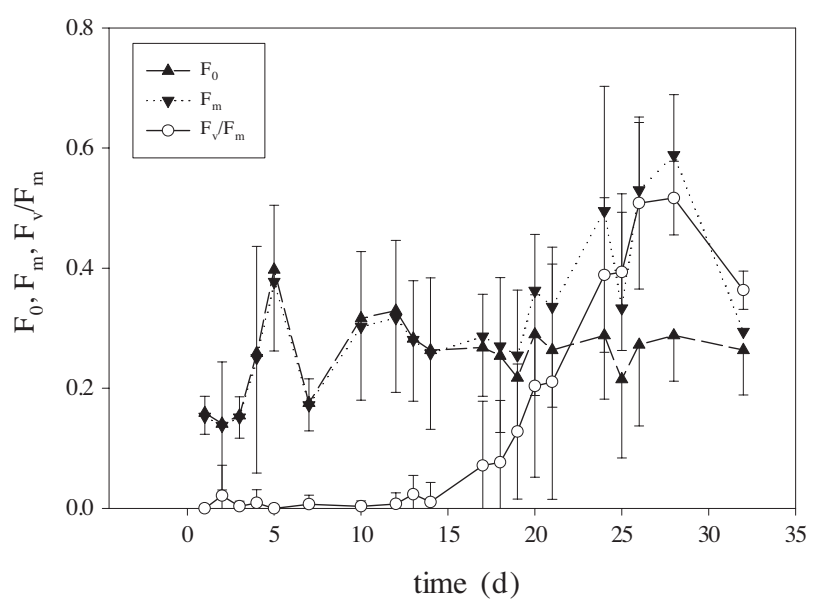

FIG. 1. - Time course of minimal $\left(\mathrm{F}_{0}\right)$ and maximum fluorescence $\left(\mathrm{F}_{\mathrm{m}}\right)$ and maximum quantum efficiency $\left(\mathrm{F}_{\mathrm{v}} / \mathrm{F}_{\mathrm{m}}\right)$ development of Cymodocea nodosa plants grown in high light during a recovery experiment after a four month dark period. Error bars represent $1 \mathrm{SD}(\mathrm{n}=7)$. 
four month dark period when reilluminated. The stable $F_{0}$ of LL plants indicates the presence of intact, but inactive photosystems. The 10 to $15 \mu \mathrm{mol}$ photons $\mathrm{m}^{-2} \mathrm{~s}^{-1}$ of indirect (reflected) light that LL plants received is in the range of light compensation points determined for this species by Olesen et al. (2002; 5.7-10.7 $\mu \mathrm{mol}$ photons $\mathrm{m}^{-2} \mathrm{~s}^{-1}$ ) and Terrados and Ros (1995; $22.9 \mu \mathrm{mol}$ photons $\mathrm{m}^{-2} \mathrm{~s}^{-1}$ ). Apparently, light levels need to be higher than the light compensation point to reactivate photosynthesis. The dynamics of the fluorescence parameters observed in HL plants can be interpreted as activating photosystems instead of synthesising new ones. However, care must be taken when interpreting individual fluorescence parameters as their meaning is ambiguous or not totally clear (reviewed by Schreiber et al., 1994, 1999). $F_{v} / F_{m}$ was still relatively low at the end of the experiment compared to the typical average 0.83 reported for unstressed higher plants (Björkman and Demmig, 1987; Magnusson, 1997) or the 0.79 average for unstressed seagrasses (calculated from values in Table 6 of the review of Touchette and Burkholder, 2000). However, until the sudden decrease on the last day of the experiment, which is probably related to interference from the phytoplankton "bloom" in the $\mathrm{HL}$ aquarium, $\mathrm{F}_{\mathrm{v}} / \mathrm{F}_{\mathrm{m}}$ showed an increasing trend and did not seem to have reached its maximum. Furthermore, it must be taken into account that measurements had to be taken from young leaves still inside the leaf sheath due to the fact that the other parts of the leaves were shed earlier in the experiment. This is normally not the main site for photosynthesis, and may therefore show a lower efficiency (Kamermans et al., 1999).

The P-I curves of both field and HL plants gave good fits with the model of Jassby and Platt, and usually explained more than $90 \%$ of the variation in over $75 \%$ of all curves. Between 75 and $90 \%$ of the variation was explained by the model in all other curves, except 3 curves (from different plants and different days) which gave unreliable fits (explaining less than $20 \%$ of the variation) and were therefore not taken into consideration. The $\mathrm{rETR}_{\mathrm{m}}, \alpha$ and $\mathrm{I}_{\mathrm{k}}$ from the HL plants increased from day 14 to day 24 and stabilised thereafter, resulting in a final $\mathrm{I}_{\mathrm{k}}$ of $97.5 \mu \mathrm{mol} \mathrm{m}^{-2} \mathrm{~s}^{-1}$ (Fig. 2). HL plants and those from the turbid intertidal pool at Caño de Cortadura had similar average $\mathrm{rETR}_{\mathrm{m}}$ and $\mathrm{I}_{\mathrm{k}}$, whereas the plants from the Río San Pedro site had a significantly higher $\mathrm{I}_{k}(\mathrm{p}<0.001)$ (Table 1). The differences in $\alpha$ and $\mathrm{rETR}_{\mathrm{m}}$ were not significant. All $\mathrm{I}_{\mathrm{k}}$ values we found were well within

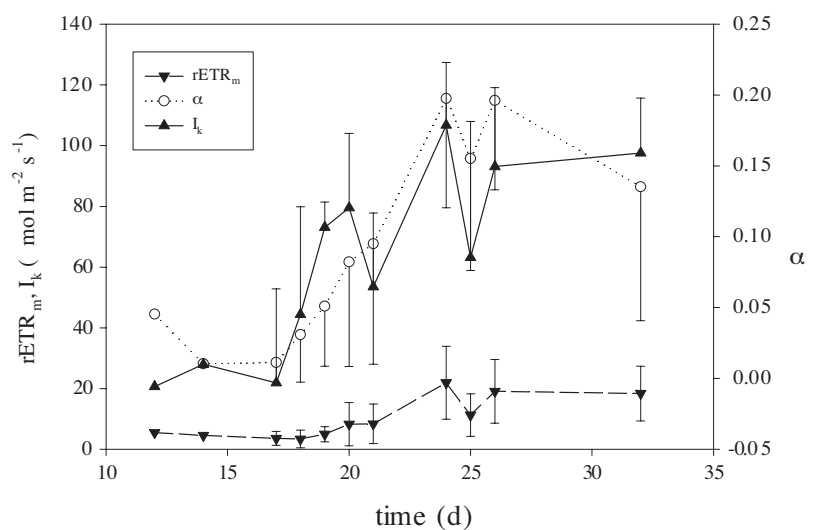

FIG. 2. - Development of parameters of photosynthesis curves: relative electron transport rate (rETRm, relative units), $\alpha$ and satura-

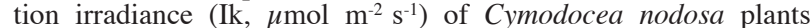
grown in high light during a recovery experiment after a four month dark period. Error bars represent $1 \mathrm{SD}(\mathrm{n}=7)$.

TABLE 1. - Average estimates $\left( \pm 1 \mathrm{SD}\right.$ ) of $\mathrm{rETR}_{\mathrm{m}}, \alpha$ and $\mathrm{I}_{\mathrm{k}}$ of rapid light curves fitted to the equation of Jassby and Platt (1980) of Cymodocea nodosa plants recovering from a 4 month dark period compared with those collected from two sites in southern Spain. $\mathrm{rETR}_{\mathrm{m}}$ and $\alpha$ in relative units, $\mathrm{I}_{\mathrm{k}}$ in $\mu \mathrm{mol}$ photons $\mathrm{m}^{-2} \mathrm{~s}^{-1}$. Significant differences (one-way ANOVA) between sites are marked: $* * *=\mathrm{p}<0.001$.

\begin{tabular}{lcccc}
\hline site & $\mathrm{n}$ & $\mathrm{rETR}_{\mathrm{m}}$ & $\alpha$ & $\mathrm{I}_{\mathrm{k}}$ \\
\hline experiment & 7 & $18.4 \pm 9.0$ & $0.14 \pm 0.01$ & $97.5 \pm 18.1$ \\
Caño Cortadura & 4 & $18.0 \pm 2.4$ & $0.24 \pm 0.03$ & $76.3 \pm 7.8$ \\
Río San Pedro & 6 & $25.0 \pm 6.6$ & $0.13 \pm 0.03$ & $190.8 \pm 23.1 * * *$ \\
\hline
\end{tabular}

the large range (26 to $230 \mu \mathrm{mol} \mathrm{m} \mathrm{m}^{-2} \mathrm{~s}^{-1}$ ) found by Terrados and Ros (1995) for this species and seem to reflect the irradiance environment in which they grow, i.e. low values for the low irradiances of the experiment and the Caño de Cortadura tidal pool and high values for the Río San Pedro tidal inlet. The fact that the photosynthetic apparatus of the HL plants shows the same acclimatisation response as field plants growing in a comparable low light environment can be seen as another indication that the plants regain normal functioning.

\section{Growth rates and biochemical composition}

The average shoot fresh weight of field samples was $391.4 \mathrm{mg}$ ( $\mathrm{SD}=60.5)$. HL plants shed their leaves (the parts above the bases) during the first week of the experiment whereas LL plants remained intact. HL plants showed a negative mean RGR $\left(-1.82 \pm 3.47 \mathrm{mg} \mathrm{FW} \mathrm{d}^{-1}\right)$, with only one plant showing a positive RGR. LL plants showed a small positive mean RGR $\left(1.88 \pm 2.97 \mathrm{mg} \mathrm{FW} \mathrm{d}^{-1}\right)$. No new production of leaves or rhizomes was observed in 
either of the aquaria. Published average leaf, rhizome and shoot plastochrone intervals for $C$. nodosa were 31.7, 28.2 and $22.9 \mathrm{~d}$ respectively (Hemminga and Duarte, 2000) and are probably longer in plants that are just starting to regain activity. Given the fact that the experiment was stopped after 32 days because of the phytoplankton bloom, it is not surprising that development of new plant organs was not observed. Considering the negative growth rates, we have to take the leaf shedding into account. Average weight loss over the entire experiment (number of experiment days $\mathrm{x}$ average RGR) was $58.2 \mathrm{mg}$ FW per plant. In plants collected from the same site in the same period we measured an average shoot (leaves + sheath) FW of $391.4 \pm 0.1 \mathrm{mg}$. Of course, leaf biomass would have changed during the cultivation period; however, it seems reasonable to assume that it was at least equal and probably larger than the $58.2 \mathrm{mg}$ average loss. This means that HL plants in fact probably gained weight after the leaf shedding, which is an indication that new tissues were being built up. Most probably this consisted of young leaves growing inside the leaf sheaths.

Leaf loss has been observed in other studies and is usually interpreted as a reaction to the need to reallocate carbohydrates and nutrients (Lee and Dunton, 1997; Longstaff and Dennison, 1999; Ruiz and Romero, 2001). In these cases, however, shedding took place during the low light period and not during the recovery period as observed in the present study. We found no reports of other species shedding their leaves during recovery and we can only speculate about its function or causes. It may be possible that although old leaves still contained active chlorophyll (as demonstrated by the high $\mathrm{F}_{0}$ measurements), the leaf structure was already too damaged to function optimally and repair was too costly compared to producing new leaves. To answer this question, the metabolic costs of leaf formation and leaf repair should be more closely studied.

Roots, shoots and rhizomes of initial plants had similar tissue C contents (Table 2). Initial plants were considerably depleted in tissue $\mathrm{C}$ in all organs compared to field plants, reaching values which are among the lowest ever measured for seagrasses in general and for C. nodosa specifically (Duarte, 1990; Ceccherelli and Cinelli, 1999). Apparently a large part of the stored carbon was respired to survive the dark period. Tissue $\mathrm{N}$ was more than two times higher in shoots than in rhizomes resulting in a lower
TABLE 2. - Tissue $\mathrm{C}$ and $\mathrm{N}$ contents (\% DW) and atomic ratio in Cymodocea nodosa plants collected from the field and after four months of dark incubation. Data are given as means $(n=4, \pm S D)$.

\begin{tabular}{llll}
\hline & tissue C & tissue $\mathrm{N}$ & $\mathrm{C}: \mathrm{N}$ \\
\hline field & & & \\
$\quad$ root + rhizome & $30.1 \pm 1.4$ & $2.0 \pm 0.3$ & $17.6 \pm 1.1$ \\
$\quad$ shoot & $30.0 \pm 2.0$ & $2.2 \pm 0.2$ & $15.7 \pm 0.9$ \\
$\begin{array}{l}\text { experiment } \\
\quad \text { root }\end{array}$ & $23.4 \pm 1.9$ & $0.6 \pm 0.1$ & $47.7 \pm 9.4$ \\
$\quad$ rhizome & $27.2 \pm 4.3$ & $0.7 \pm 0.1$ & $43.9 \pm 11.4$ \\
shoot & $23.6 \pm 4.0$ & $1.9 \pm 0.6$ & $14.7 \pm 2.6$ \\
\hline
\end{tabular}

shoot $\mathrm{C}: \mathrm{N}$ ratio and a higher root/rhizome $\mathrm{C}: \mathrm{N}$ ratio. Tissue $\mathrm{N}$ was only lower in rhizomes of initial plants compared to those of field plants. The $\mathrm{C}: \mathrm{N}$ ratio of belowground parts of field plants was almost three times lower than in initial plants (Table 2). The causes of this strong rise in C:N remain speculative. Possible explanations include partial decomposition of roots and rhizomes during the dark incubation or nitrogen reallocation to the shoots in order to support the aboveground structures.

Rhizome sucrose content was highest in initial plants and significantly lower in HL plants ( $p<0.05$, Fig. 3). Both LL and HL plants had consumed all sucrose in their shoots. Starch content showed relatively low and nearly equal values in all plant parts under all conditions (initial, HL, LL), $4.3 \pm 1.4 \mathrm{mg} / \mathrm{g}$ DW on average (not shown). This indicates that starch plays a minor role compared to sucrose as a carbon reserve in Cymodocea nodosa, as was previously shown for Zostera noltii (Brun et al., 2002). The

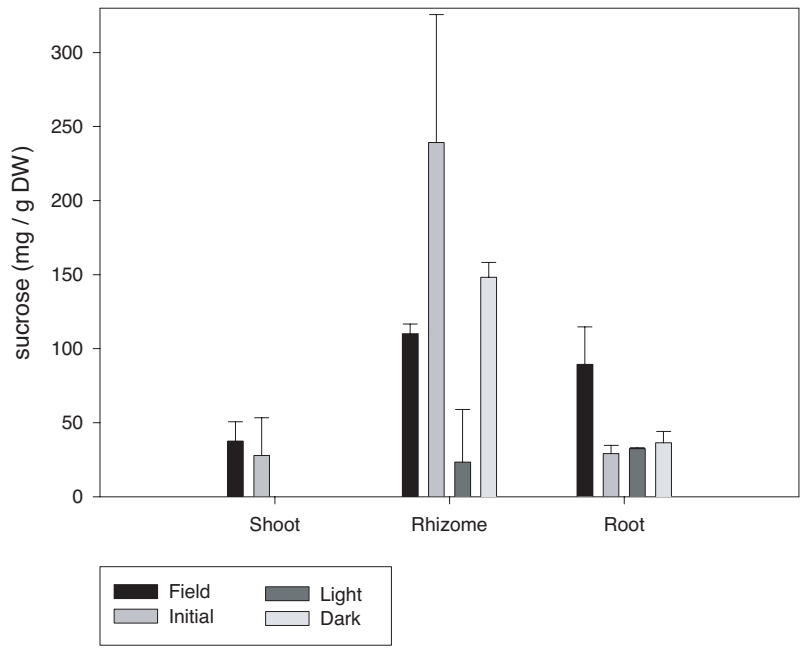

FIG. 3. - Sucrose (mg/g DW) in shoots, rhizomes and roots of Cymodocea nodosa plants freshly collected from the field ("field"), after a four month dark period ("initial") and after a subsequent recovery experiment in very low light ("LL") and high light ("HL"). Error bars represent $1 \mathrm{SD}(\mathrm{n}=7)$. 
420 - E.-J. MALTA et al.

TABLE 3. - Reported survival times for seagrasses subjected to a period of (near) darkness. SI $=$ surface irradiance, $\mathrm{m}=\mathrm{month}(\mathrm{s}), \mathrm{w}=\mathrm{weeks}$, $\mathrm{d}=$ days.

\begin{tabular}{lccl}
\hline species & light availability & time survived & source \\
\hline $\begin{array}{l}\text { Cymodocea nodosa } \\
\text { Halodule pinifolia }\end{array}$ & 0 & $>4 \mathrm{~m}$ & this study \\
Halophila ovalis & 0 & $80 \mathrm{~d}(90-100 \mathrm{~d}$ predicted $)$ & Longstaff and Dennison, 1999 \\
Heterozostera tasmanica & 0 & $1 \mathrm{~m}$ & Longstaff et al., 1999 \\
Zostera marina & $2 \%$ of SI & $2 \mathrm{~m}$ & Bulthuis, 1983 \\
Zostera noltii & $1 \%$ of SI & $3 \mathrm{w}$ & Cabello-Pasini et al., 2002 \\
& & $2 \mathrm{w}$ & Brun et al., 2003 \\
\hline
\end{tabular}

slight decrease in sucrose content in LL plants compared to values in initial plants, again implies that maximum survival time may well exceed the four months reported in this study. The drop in shoot sucrose in the plants during the recovery experiment is most probably due to the ramets being cut up into experimental units, which deprived them of a large part of their rhizome source of sucrose (Terrados et al., 1997b; Marbà et al., 2002). The additional sucrose depletion in the rhizomes of HL plants compared to LL plants may be another indication of plant reactivation. Sucrose may have been respired and used to reactivate the photosynthetic apparatus of the young leaves inside the sheaths or initiate the development of new leaves, which would agree with the weight gain explained above. However, more and especially longer experiments are required to test these hypotheses.

The recovery of photosynthesis and the recuperation of biomass after leaf loss are strong indications that $C$. nodosa may indeed be capable of a complete recovery after four months in the dark. This is in agreement with the results of Marbà and Duarte (1994), which showed that C. nodosa seedlings were able to survive being buried to considerable depths, thereby also supporting prolonged periods of total darkness. Z. noltii, however, died during the dark incubation. This is in agreement with the hypothesis that smaller seagrasses are less able to survive adverse conditions than larger ones, because the latter have more extensive rhizome systems which allow more carbohydrates to be stored (Onuf, 1996; Longstaff et al., 1999; Brun et al., 2003). Reported survival times of seagrasses under light deprivation vary widely from as short as two weeks (Zostera marina, no light, Cabello-Pasini et al., 2002) to 24 months (Posidonia sinuosa, $10 \%$ of surface irradiance, Gordon et al., 1994). Studies where plants were subjected to (near) darkness showed that the dark incubation period tested here is the longest reported for a seagrass so far (Table 3). Remarkably, only the apical shoots survived the dark period, which was not observed in other light deprivation studies. In many seagrass species, apical shoots draw resources away from the other shoots (Marbà et al., 2002). In particular, for $C$. nodosa it has been shown that apical shoots are dominant over the other shoots in terms of growth and resource mobilisation (Terrados et al., 1997a, b); however, this extreme kind of dominance in which all other shoots are sacrificed for the growth of the apical has not been reported before.

In conclusion, $C$. nodosa is capable of reactivating photosynthesis after a four month dark period. This is the longest period reported so far for a seagrass species. In addition, there are strong indications that these plants can completely recover by remobilising their pool of stored carbohydrates, especially sucrose. Considering the fact that carbohydrate reserves were not exhausted and intact chlorophyll still appeared to be present in the low light plants, it can be expected that this period can even be extended. The high tolerance of $C$. nodosa to temporal periods of low or even zero irradiance levels compared to the low tolerance of other seagrasses is important in elucidating the processes that lead to species composition in mixed seagrass stands after disturbances and should be taken into account when conservation policies are developed.

\section{ACKNOWLEDGEMENTS}

The authors thank Augusto Martínez (University of Málaga) for the C:N analyses. EjM is supported by a Marie Curie fellowship of the European Community Programme "Energy, Environment and Sustainable Development" (contract no. EVK3-CT-2000-50003) and a Marie Curie Reintegration Grant (contract no. MERG-CT-2004-006385), FGB holds an individual Marie Curie fellowship (contract no. MEIF-CT-2005- 
515071). Additional support was provided by the Spanish Ministry for Science and Technology (project REN 2002-00746/MAR). The authors wish to thank the two anonymous referees and the scientific editor of Scientia Marina for their helpful comments on earlier versions of the manuscript.

\section{REFERENCES}

Beer, S. and M. Björk. - 2000. Measuring rates of photosynthesis of two tropical seagrasses by pulse amplitude modulated (PAM) fluorometry. Aquat. Bot., 66: 69-76.

Bischof, K., D. Hanelt and C. Wiencke. - 2000. Effects of ultraviolet radiation on photosynthesis and related enzyme reactions of marine macroalgae. Planta, 211: 555-562.

Björkman, O. and B. Demmig. - 1987. Photon yield of $\mathrm{O}_{2}$ evolution and chlorophyll fluorescence characteristics at $77 \mathrm{~K}$ among vascular plants of diverse origins. Planta, 170: 489-504.

Box, G.E.P. and D.R. Cox. - 1964. An analysis of transformations. J. Roy. Stat. Soc. B, 26: 211-234.

Brun, F.G., I. Hernández, J.J. Vergara, G. Peralta and J.L. PérezLloréns. - 2002. Assessing the toxicity of ammonium pulses to the survival and growth of Zostera noltii. Mar. Ecol. Progr. Ser., 225: 177-187.

Brun, F.G., I. Hernandez, J.J. Vergara and J.L. Pérez-Lloréns. 2003. Growth, carbon allocation and proteolytic activity in the seagrass Zostera noltii shaded by Ulva canopies. Funct. Plant Biol., 30: 551-560.

Bulthuis, D.A. - 1983. Effects of in situ light reduction on density and growth of the seagrass Heterozostera tasmanica (Martens ex Aschers) den Hartog in Western Port, Victoria, Australia. J. Exp. Mar. Biol. Ecol., 67: 91-103.

Cabello-Pasini, A., C. Lara-Turrent and R.C. Zimmerman. - 2002. Effect of storms on photosynthesis, carbohydrate content and survival of eelgrass populations from a coastal lagoon and the adjacent open ocean. Aquat. Bot., 74: 149-164.

Ceccherelli, G. and F. Cinelli. - 1999. A pilot study of nutrient enrichment sediments in a Cymodocea nodosa bed invaded by the introduced alga Caulerpa taxifolia. Bot. Mar., 42: 409-417.

Duarte, C.M. - 1990. Seagrass nutrient content. Mar. Ecol. Progr. Ser., 67: 201-207.

Enríquez, S., M. Merino and R. Iglesias-Prieto. - 2002. Variations in the photosynthetic performance along the leaves of the tropical seagrass Thalassia testudinum. Mar. Biol., 140: 891-900.

Gordon, D.M., K.A. Grey, S.C. Chase and C.J. Simpson. - 1994. Changes to the structure and productivity of a Posidonia sinuosa meadow during and after imposed shading. Aquat. Bot., 47: 265-275.

Hanelt, D. - 1992. Photoinhibition of photosynthesis in marine macrophytes of the South Chinese Sea. Mar. Ecol. Progr. Ser., 82: $199-206$

Hanelt, D. - 1998. Capability of dynamic photoinhibition in Arctic macroalgae is related to their depth distribution. Mar. Biol., 131: 361-369.

Hauxwell, J., J. Cebrián, C. Furlong and I. Valiela. - 2001. Macroalgal canopies contribute to eelgrass (Zostera marina) decline in temperate estuarine ecosystems. Ecology, 82: 1007-1022.

Hemminga, M.A. and C.M. Duarte. - 2000. Seagrass Ecology. Cambridge University Press, Cambridge.

Hubber, S.C. and D.W. Israel. - 1982. Biochemical basis for partitioning of photosynthetically fixed carbon between starch and sucrose in soybean (Glycine max Merr.) leaves. Plant Physiol., 69: 691-696

Jassby, A.D. and T. Platt. - 1976. Mathematical formulation of the relationship between photosynthesis and light for phytoplankton. Limnol. Oceanogr., 21: 540-547.

Kamermans, P., M.A. Hemminga and D.J. de Jong. - 1999. Significance of salinity and silicon levels for growth of a formerly estuarine eelgrass (Zostera marina) population (Lake Grevelingen, The Netherlands). Mar. Biol., 133: 527-539.

Lee, K.-S. and K.H. Dunton. - 1997. Effects of in situ light reduc- tion on the maintenance, growth and partitioning of carbon resources in Thalassia testudinum Banks ex König. J. Exp. Mar. Biol. Ecol., 210: 53-73.

Longstaff, B.J. and W.C. Dennison. - 1999. Seagrass survival during pulsed turbidity events: the effects of light deprivation on the seagrasses Halodule pinifolia and Halodule ovalis. Aquat. Bot., 65: 105-121.

Longstaff, B.J., N.R. Loneragan, M.J. O'Donohue and W.C. Dennison. - 1999. Effect of light deprivation on the survival and recovery of the seagrass Halophila ovalis (R. Br.) Hook. J. Exp. Mar. Biol. Ecol., 234: 1-27.

Magnusson, G. - 1997. Diurnal measurements of $F_{v} / F_{m}$ used to improve productivity estimates in macroalgae. Mar. Biol., 130: 203-208.

Marbà, N. and C.M. Duarte. - 1994. Growth response of the seagrass Cymodocea nodosa to experimental burial and erosion. Mar. Ecol. Progr. Ser., 107: 307-311.

Marbà, N., M.A. Hemminga, M.A. Mateo, C.M. Duarte, Y.E.M. Maas, J. Terrados and E. Gacia. - 2002. Carbon and nitrogen translocation between seagrass ramets. Mar. Ecol. Progr. Ser., 226: $287-300$.

McGlathery, K.J. - 2001. Macroalgal blooms contribute to the decline of seagrass in nutrient-enriched coastal waters. $J$. Phycol., 37: 453-456.

Moore, K.A., R.L. Wetzel and R.J. Orth. - 1997. Seasonal pulses of turbidity and their relations to eelgrass (Zostera marina L.) survival in an estuary. J. Exp. Mar. Biol. Ecol., 215: 115-134.

Olesen, B., S. Enríquez, C.M. Duarte and K. Sand-Jensen. - 2002. Depth-acclimation of photosynthesis, morphology and demography of Posidonia oceanica and Cymodocea nodosa in the Spanish Mediterranean Sea. Mar. Ecol. Progr. Ser., 236: 89-97.

Onuf, C. - 1996. Seagrass responses to long-term light reduction by brown tide in upper Laguna Madre, Texas: distribution and biomass patterns. Mar. Ecol. Progr. Ser., 138: 219-231.

Peralta, G., J.L. Pérez-Lloréns, I. Hernández and J.J. Vergara. 2002. Effects of light availability on growth, architecture and nutrient content of the seagrass Zostera noltii Hornem. J. Exp. Mar. Biol. Ecol., 269: 9-26.

Ralph, P.J. and M.D. Burchett. - 1995. Photosynthetic responses of the seagrass Halophila ovalis (R. Br.) Hook f. to high irradiance stress, using chlorophyll $a$ fluorescence. Aquat. Bot., 51: 55-66.

Ralph, P.J., R. Gademann and W.C. Dennison. - 1998. In situ seagrass photosynthesis measured using a submersible, pulseamplitude modulated fluorometer. Mar. Biol., 132: 367-373.

Ruiz, J.M. and J. Romero. - 2001. Effects of in situ experimental shading on the Mediterranean seagrass Posidonia oceanica. Mar. Ecol. Progr. Ser., 215: 107-120.

Schreiber, U., W. Bilger and C. Neubauer. - 1994. 3 Chlorophyll fluorescence as a nonintrusive indicator for rapid assessment of in vivo photosynthesis. In: E.D. Schulze and M.M. Caldwell (eds.), Ecophysiology of photosynthesis, pp. 49-70. Springer, Berlin.

Schreiber, U., W. Bilger, H. Hormann and C. Neubauer. - 1999. Chlorophyll fluorescence as a diagnostic tool: basics and some aspects of practical relevance. In: D.O. Hall and K.K. Rao (eds.), Photosynthesis, pp. 321-336. Cambridge University Press, Cambridge.

Short, F.T., D.M. Burdick and J.E. Kaldy. - 1995. Mesocosm experiments quantify the effects of eutrophication on eelgrass, Zostera marina. Limnol. Oceanogr., 40: 740-749.

Short, F.T. and S. Wylie-Echeverria S. - 1996. Natural and human-induced disturbance of seagrasses. Environ. Conserv., 23: $17-27$

Sokal, R.R. and F.J. Rolhf. - 1995. Biometry. 3rd edition. Freemand and Company, New-York.

Spjøtvoll, E. and M.R. Stoline. - 1973. An extension of the Tmethod of multiple comparison to include the cases with unequal sample sizes. J. Am. Stat. Assoc., 68: 976-978.

StatSoft. - 1999. STATISTICA for Windows (Computer program manual). StatSoft Inc.

Terrados, J., C.M. Duarte, and W.J. Kenworthy. 1997a. Experimental evidence for apical dominance in the seagrass Cymodocea nodosa. Mar. Ecol. Progr. Ser. 148: 263-268.

Terrados, J., C.M. Duarte, and W.J. Kenworthy. 1997b. Is the apical growth of Cymodocea nodosa dependent on clonal integration? Mar. Ecol. Progr. Ser. 158: 103-110.

Terrados, J. and J.D. Ross. 1995. Temperature effects on photosyn- 
422・ E.-J. MALTA et al.

thesis and depth distribution of the seagrass Cymodocea nodosa (Ucria) Ascherson in a Mediterranean coastal lagoon: the Mar Menor (SE Spain). PSZNI Mar. Ecol. 16: 133-144.

Touchette, B.W. and J.M. Burkholder. - 2000. Overview of the physiological ecology of carbon metabolism in seagrasses. $J$. Exp. Mar. Biol. Ecol. 250: 169-205.

White, A.J. and C. Critchley. - 1999. Rapid light curves: a new fluorescence method to assess the state of the photosynthetic appa- ratus. Photosynth. Res. 59: 63-72.

Yemn, E.W. and A.J. Willis. - 1954. The estimation of carbohydrates in plant extracts by anthrone. Biochem. J. 57: 508-514.

Scient. ed.: I. Valiela

Received November 9, 2004. Accepted March 23, 2006.

Published online July 5, 2006. 